\title{
Expression of concern: Prevalence of hepatitis B and hepatitis $C$ infection in Libya: results from a national population based survey
}

Philippa K Harris

Following publication of this article (Daw and El-Bouzedi, BMC Infectious Diseases 2014, 14:17) [1] it has been brought to the Editors' attention that much of this data appears to have been previously published in the following article [2]. In addition concerns about the authors' right to use this data have been raised. Despite extensive efforts to obtain an independent investigation, we have been unable to secure advice on the matter. Given the uncertainty, the Editors advise the readers to interpret the data with due caution. We apologize to all affected parties.

Received: 13 January 2015 Accepted: 20 January 2015

Published online: 19 February 2015

\section{References}

1. Daw MA, El-Bouzedi A. Prevalence of hepatitis B and hepatitis C infection in Libya: results from a national population based survey. BMC Infect Dis. 2014;14:17.

2. Elzouki NA, Smeo MN, Sammud M, Elahmer O, Daw M, Furarah A, et al. Prevalence of hepatitis $B$ and $C$ virus infections and their related risk factors in Libya: a national seroepidemiological survey. East Mediterr Health J. 2013;19(7):589-99.

Submit your next manuscript to BioMed Central and take full advantage of:

- Convenient online submission

- Thorough peer review

- No space constraints or color figure charges

- Immediate publication on acceptance

- Inclusion in PubMed, CAS, Scopus and Google Scholar

- Research which is freely available for redistribution 